proach (Wadsworth, 2000); Environmental Politics and Policy: Theories and Evidence (Duke University Press, 1995); Implementation Theory and Practice: Toward a Third Generation (Harper Collins, 1990); Dimensions of Hazardous Waste Politics and Policy (Greenwood Press, 1988); and The Politics of Hazardous Waste Management (Duke University Press, 1983). A posthumous coauthored book, Environmental Injustice in the United States: Myths and Realities, was in press at the time of his death and will be published in October 2000 by Westview Press.

Jim is survived by his wife, Sally A. Lester; one daughter, Elizabeth Munson Lester; two step-daughters, Melisa McTague and Nicole McTague; and one brother, William Howard Lester of San Francisco. Memorial contributions may be made to the Friends of Pingree Park, 1005 W. Laurel St., Fort Collins, $\mathrm{CO} 80523$, in remembrance of Jim's deep appreciation of the environment.

David W. Allen, Colorado State University

\section{Mary T. Reynolds}

Mary T. Reynolds, 87, who began her career as a political scientist in the 1940s, died of non-Hodgkin's lymphoma this past summer at her home in Washington, DC.

Dr. Reynolds taught at several schools including Hunter, Brooklyn, and Queens Colleges in New York and Johns Hopkins University in Baltimore.

In the early 1960 s, having become frustrated with what she saw as barriers to female political scientists and wanting to pursue a career in literary scholarship she had earlier considered impractical, she began studying the work of James Joyce.

She published her first Joyce book, Joyce and Nora, in 1964 while working as a research associate in economics at Yale University. She became a visiting professor in English at Yale in the 1970s and was affiliated with the university until 1989, when she moved to Washington.

In 1981, Dr. Reynolds published Joyce and Dante: The Shaping Imagination (Princeton University Press), which one Joyce scholar called the definitive commentary on Dante's influence on Joyce. And, during the early 1990s, Dr. Reynolds played a key role in seeing Joyce's Ulysses published in Chinese translation.

Mary Trackett Reynolds received bachelor's and master's degrees in political science from the University of Wisconsin, Madison and her doctorate in political science from $\mathrm{Co}-$ lumbia University. She is survived by her husband of 63 years, Lloyd G.

Reynolds; two daughters, Anne R.

Skinner and Priscilla R. Roosevelt; a son, Bruce L. Reynolds; seven grandchildren, and two great-grandchildren.

Adapted from Adam Bernstein, "Mary T. Reynolds Dies," The Washington Post, August 25, B6.

\section{John L. Stanley}

With the death of John Langley Stanley in February of 1998, the University of California, Riverside and the entire scholarly world lost a brilliant teacher of political philosophy and an internationally respected scholar. To his wife, Charlotte, and their three children, Andrea, John (Jay) and Margo, the loss of the deeply loving and equally beloved father and husband cannot be measured. In an important way, John Stanley lived deep within his family and they with him.

John's students delivered their own message about the loss of this superb teacher in the form of a surprising number of letters and telephone and email messages to the political science department. The gist of the collective expression was that John was one of the best or the best teacher any of them had ever encountered. But those of us in political science already knew that, as we had been hearing it from students for three decades in both faceto-face encounters and in the mass from their comments on the course evaluation forms. In the corridors of Watkins Hall, Stanley was a striking and unforgettable physical presence for over 30 years. Partly, this was due to his restless vitality, but it was mostly due to his resonant voice articulating a flawless American English. For many of us, it is hard to live with the thought of not hearing him again in the corridors or at meetings.
John L. Stanley was born in Boston, Massachusetts, in November, 1937 , and spent his early years in the town of Newton. His family later moved to Rye, New York, where he was educated in the public schools. He matriculated at Kenyon College and graduated with honors in political science in 1960. Stanley then enjoyed a year at Selwyn College of Cambridge University, where he studied modern European history. In 1961, he enrolled in the doctoral program of the government department at Cornell University, after being awarded a prestigious Woodrow Wilson Fellowship. While at Cornell, he concentrated on political theory, particularly the intellectual contributions of Georges Sorel.

In the fifties and sixties, Sorel's reputation was at its nadir. Cursed as an apostle of violence or a precursor of fascism (Sartre labeled his works "fascist utterances"), or as an advocate of elitism as well as having been dismissed by Lenin as a "professor of confusion," Sorel appeared to be ready for the dustbin of history. John Stanley saved him from this fate. While still in graduate school, and before arriving at UCR in 1965, Stanley, with the collaboration of his wife, Charlotte, began a translation of Sorel's The Illusions of Progress. That translation was published in 1969 to a warm critical welcome. The work included an extended introduction by John that set the stage for the modern study of Sorel. John's project was not to rehabilitate Sorel, although some rehabilitation was accomplished by the time he had finished writing about Sorel. Rather, John wanted to make a thorough and analytical investigation of the corpus of Sorel's works.

He showed Sorel's work to be nuanced and learned, though not popular in an age in love with the doctrine of progress. In From Georges Sorel: Essays in Socialism and Philosophy, a compilation of selections of Sorel's works translated by John and Charlotte that also included an introduction by John, he continued his serious close examination of Sorel and, along the way, convincingly shattered the notion that Sorel was a precursor of fascism or a reaction- 
ary authoritarian. His masterwork on Sorel was The Sociology of Virtue: The Political and Social Theories of Georges Sorel, published in 1981. That established John's reputation as, arguably, the world's leading authority on Sorel. Two other translations followed, including a work that Sorel wrote in Italian, the translation of which required John to learn Italian from scratch. John's last Sorel book, published in 1990, was From Georges Sorel, Volume 2: Hermeneutics and the Sciences, in which he presented and analyzed Sorel's writings on interpretive problems in religion, art, science, and political theory. There are few testable hypotheses in political theory, yet John was always alert to the possibility of finding counterexamples to his own beliefs and those of others. A memorable example was his response to Hannah Arendt, who had proposed that totalitarianism was an invention of the twentieth century. In a 1987 Review of Politics article, John pointed out features of Shaka's rule of the Zulu empire in the early nineteenth century that corresponded to Arendt's definition of totalitarianism. To look beyond the traditional domains of Europe and Asia was typical of the originality and compass of John's thought.

With the same intellectual courage and insight that led him to Sorel, John, acting on Hegel's dictum that "the owl of Minerva rises at dusk," turned his attention toward Marx, specifically to challenging the stance of a group of "Western Marxists" who were attempting to present "Marxism with a human face," dissociating him from Engels and "scientific determinism." John would have none of this, and proceeded, in a series of five articles in scholarly journals, to delve into the early Marx, Marx's critique of Hegel, and his relation to Engels' dialectics of nature. Along the way, John demonstrated his originality and changed more than a few scholars' views of Marx. He was well into writing a comprehensive work on "Marx's View of Nature" when, alas for the world of Marx scholarship, as well as for all of us who knew him, his last illness took him with shocking suddenness.
Turning to his teaching, John had a larger than life persona in the classroom. He was a blithe spirit, full of buoyancy and vitality. He had a fine speaking voice that he inherited from his father, who had migrated to this country from England and become a successful radio actor, succeeding Basil Rathbone as Sherlock Holmes on the Mutual Broadcasting Network. John was a man of multiple gifts, and the most striking was his skill as a lecturer. He was an exemplary lecturer in political philosophy and theory, classes that drew large crowds. His lectures combined wit, vast learning in classical, medieval, and modern political theory, love of his subject, and theatricality. He was able to hold student interest while discussing abstruse and unfamiliar themes. Young Americans live and breathe individualism, and John had to introduce them to cultures where individualism scarcely existed as a concept. His students frequently commented on the difficulty of the subject as they were taken through theory "from Plato to NATO," as he called his year-long series of political theory courses. He drew large crowds despite the difficulty students had understanding Hegel and Marx and despite John's fairly tough grading.

He was as much at home in the graduate seminar as in the lecture hall. Again, the subject matter was difficult, but many students were so attached to John that they went on to do their dissertations under his direction. He was invariably generous with his time and attention. Those of us who shared the hallway with him over the years had the common experience of knocking on his door long after 5:00 p.m., hoping for a brief word and finding him deep in discussion with a thesis student. "Later dear boy!" he would call and turn again to the student. He enjoyed being a dissertation director. He would survey language, grammar, punctuation, and figures of speech, as well as substance and statistics. However, he was not a controller, even if the student wanted him to be one. His students wrote about Arendt, Ellul, Aron, and Sartre, among others.

In this age of grade inflation,
John Stanley was a pillar of tradition and rectitude. It was extremely difficult to get an " $A$ " in his courses. The " $D$ " and " $F$ " were not dead letters in his grading system. He always assigned term papers, even in the larger courses, and never gave "objective" exams. His rule was that he would read something by every student, no matter how many TAs there were to assist him, and every student was required to speak to him personally about the choice of a subject for the paper. He had learned the importance of establishing a direct relationship with students at Cornell, where he studied with Mario Einaudi and Andrew Hacker. Both were great teachers renowned for the amount of time they gave to their students' work. John hoped that word of his success would filter back to Ithaca, and some of us who knew them made sure they were aware of John's accomplishments as a teacher and scholar. They were not surprised.

John's breadth and charm inspired enduring friendships across the campus, from his colleagues in mathematics and the sciences to those in the fine arts. He was an academic type who, alas, is becoming an endangered species in the humanities and social sciences: a "triple threat." He could teach brilliantly, publish frequently, and do service for the campus enthusiastically; and all at the same time. His speeches at faculty senate meetings were memorable for their wit and substance. He served on the Committee on Academic Personnel (as chair during his third year) on which his high but fair standards, no doubt, found a receptive audience. The last two years of his life were spent representing the University of California as its associate director of the British study center in London. Here, he showed a fourth talent, one that few would have predicted he would posses-a talent for administration. He brought light, wit, and an evergreen charm to our lives. We miss him.

Francis Carney,

University of California, Riverside Kenneth Barkin Thomas Morton 